\title{
PUNITIVE DAMAGES IN DEFAMATION LITIGATION: A CLEAR AND PRESENT DANGER TO FREEDOM OF SPEECH*
}

Defamation is the tort of communicating material which is injurious to a person's reputation. ${ }^{1}$ If the communication is libelous ${ }^{2}$ or slanderous per $\mathrm{se}^{\text {" }}$ general damages will be imposed according to the jury's estimate of the plaintiff's injury. ${ }^{4}$ And if the plaintiff can show specific financial injury

\section{*Reynolds v. Pegler, 123 F. Supp. 36 (S.D.N.Y. 1954).}

1. Rocky Mountain News Printing Co. v. Fridborn, 46 Colo. 440, 104 Pac. 956 (1909): Prosser, ToRTS $\S 91$ (1941); HARper, TorTs $\S 235$ (1933). The term includes not only natural persons but also corporations and partnerships. Ohio and M. Ry. Co. v. Press Pub. Co., 48 Fed. 206 (C.C.S.D.N.Y. 1891); New York Society for the Suppression of Vice v. MacFadden Publications, 221 N.Y. Supp. 563, 129 Misc. 408 (1927).

2. Libel originally consisted of written defamatory matter. Recently it has come to include other defamations which are similar to writing or printing in their permanence of form or potentiality of harm. Libel is divided into two categories: matter which is "libelous upon [its] face" H Pandolfo v. Bank of Benson, 273 Fed. 48 (1921), and matter which is libelous only with reference to a particular individual, situation or context, e.g., Lemmer v. The Tribune, 50 Mont. 559, 148 Pac. 338 (1915). This latter category is sometimes called libel per quot. Flake v. Greensboro News Co., 212 N.C. 780, 785, 195 S.E. 55, 59 (1938). A few courts have apparently held that libel per quod is actionable only when there is proof of special damages. See id. See also Note, 26 Iowa L. Rev. 893 (1941); Note, 25 Mrcu. L. REv. 551 (1927). The general rule is that no allegation of special damages is required in any libel suit. McCoknsick, Darrages § 113 (1935).

3. Slander historically meant oral defamation. However, the distinction between slander and libel is now unclear in certain areas. See Prosser, TORTS $\$ 92$ (1941).

An action for slander may be brought without alleging special damages only where the slander is actionable per se. Included in this category are slanders imputing serious crinte, Earley v. Winn, 129 Wis. 291, 109 N.W. 633 (1906), loathsome discase, Sally v. Brown, 220 Ky. 576, 295 S.W. 890 (1927), unchastity, Battles v. Tyson, 77 Neb. 563, 110 N.W. 299 (1906), or harming one's repute in trade, business or profession, Hickerson v. Masters, 190 Ky. 168, 226 S.W. 1072 (1921).

4. "Where words are published of the plaintiff which constituted a libel, . . . the law presumes that the plaintiff has been damaged, without proof of any special damage, because the law takes notice of the fact that a libel travels, and it comes to a great many different readers, and that it would be impossible for a plaintiff to trace out the circulation of the libel, and show by whom it had been read, and how it had affected their opinion of him and all that; so that the jury are justified in allowing stubstantial datmages to a plaintiff against whom a libel has been published, without proof of any particular or substantial damages to him." Washington Post v. Chaloner, 250 U.S. 290, 292 (1919). Mental suffering, decline of repute, and probable decline of financial status are covered by general damages. Stevenson v. Hearst Consol. Publications, 214 F.2d 902 (2d Cir.), cert. denied, 348 U.S. 874 (1954); Craney v. Donavan, 92 Conn. 236, 102 Atl. 640 (1917) ; Poleski v. Polish American Pub. Co., 254 Mich. 15, 235 N.W. 841 (1931). See also McCorartck, Daniages $\$ 116$ (1935) ; Thayer, Legal Control of the Press $\$ 57$ (1950) ; 22 Colung. L. Rev. 678 (1922) ; 8 CoRnell L.Q. 65 (1922) ; 36 Hakv. L. Rev. 226 (1922) ; 3 U. Newark L. Rev. 182 (1938). 
special damages are also available in these cases and in the remaining slander actions. ${ }^{5}$ Both general and special damages are compensatory awards designed primarily to rehabilitate the injured party and only incidentally to punish the tortfeasor. ${ }^{6}$ There the jury finds that the defendant's conduct was particularly reprehensible or malicious it may also impose punitive damages. ${ }^{7}$ Such damages are designed to punish wrongdoers, ${ }^{8}$ to discourage similar torts, ${ }^{\theta}$ and to encourage private policing in fields where suitable public action is not practical. $^{\mathbf{1 0}}$

In the recent case of Reynolds $v$. Pegler, ${ }^{11}$ plaintiff alleged that defendants had written, published, and disseminated material injurious to plaintiff's reputation. ${ }^{12}$ The jury found for the plaintiff and awarded him nominal damages of one dollar against each of the three defendants. ${ }^{13}$ Punitive damages totalling $\$ 175,000$ were also assessed against the defendants. ${ }^{14}$ The defense moved to set aside the verdict on the ground that punitive damages were excessive in view of the assessment of only nominal general damages. The court refused to disturb the jury's award of punitive damages because the amount was not so clearly "excessive as to shock the judicial conscience."1s

5. Special damages are only awarded when actual financial injury is proved. Hanres, TORTS $\$ 242$ (1933).

6. Cf. Morris, Punitic'e Damages in Tort Cases, 44 Harv. L. Rex. 1173 (1931); Morris, Rough Justice and Some Vtopian Idias, 24 ILL. L. REv. 730 (1930).

7. Forrester v. Southern Pac. Co., 36 Nev. 247, 134 Pac. 753 (1913). Sce also MlcCormick, Damages $\$ 79$ (1935); Note, 10 Brooklyn L. Rev. 292 (1941); 3 U. Newask L. REv. 182 (1938). Several states have general code provisions which specifically authorize punitive damages. See, e.g., CAL. Crr. CODE $§ 3294$ (1949).

8. Voltz v. General Motors Acceptance Corp., 332 Pa. 141, 2 ^.2d 697 (1938).

9. Bucher v. Krause, 200 F.2d 576 (7th Cir.), cert. denied, 345 U.S. 997 (1953).

10. Neal v. Newburger, 154 Miss. 691, 123 So. 861 (1920). See McConnck, D.ssums $\S 77$ (1935).

11. 123 F. Supp. 36 (S.D.N.Y. 1954).

12. The author was columnist Westbrook Pegler. The Hearst Curp. distributed the columns in which the defamatory material appeared to 186 newspapers with a combined nationwide circulation of 12,000,000. And Hearst Consolidated Publications published the column in its newspaper having a circulation of 743,000. Reynolds v. Pegler, $123 \mathrm{~F}$. Supp. 36, 41 (S.D.N.Y. 1954).

13. "Nominal damages are a sum which is held to be recoverable where a legal right is to be vindicated against an invasion which has produced no actual present loss of any kind." Press v. Davis, 118 S.W.2d 982, 995 (Tex. Civ. App. 1938). See also 10 خorke Danse Law. 133, 134 n.1 (1935); 18 U. Cix. L. Rex. 545 (1949). "Small damages, however, and nominal damages do not mean the same thing." Chapin v. Babcock, 67 Conn. 255, 257, 34 Atl. 1039 (1896).

14. The award was apportioned as follows: $\$ 100,000$ against defendant Pegler, $\$ 50,000$ against the Hearst Corporation, and $\$ 25,000$ against Hearst Consolidated Publicationc. Reynolds v. Pegler, 123 F. Supp. 36, 41 (S.D.N.Y. 1954).

15. Ibid. The court held that no relationship between punitive and actual damages was necessary and that "there are of course, limits upon the jury's power; but unless the amount of the penalty is so clearly excessive as to compel the conclusion that it is the result of passion or prejudice, its award should not be disturbed." Id. at 39. 
The rationale of punitive damage awards is seriously to be questioned.10 Punishment should have little place in civil actions, which are designed primarily to make whole the injured party. ${ }^{17}$ The deterrent value of punitive damages is negligible. ${ }^{18}$ And in almost all cases in which such damages may be awarded appropriate criminal action could be taken with more desirable results. ${ }^{10}$ Moreover, puntive damages are assessed in civil trials in which the defendant is deprived of the guarantees present in a criminal proceding. ${ }^{20}$ And punitive awards may be imposed in addition to criminal penalties. For all practical purposes this subjects the defendant to dotible jeopardy for the same offense. ${ }^{21}$ Finally, there is no justification for plaintiff's enrichment by

16. See MCCormick, Damages $\S 77$ (1935).

17. The theory and purpose of the two actions differ. "Ordinarily the administration of the laws is divided into two distinct jurisdictions, the civil and the criminal, each governed by rule of procedure and by rules governing the admission and weight of testimony different and distinct from the other .... And it is to the criminal and not to the civil jurisdiction that society looks for its protection against criminals." Spokane Truck and Dray Co. v. Hoefer, 2 Wash. 45, 53 (1891).

18. Certain tortfeasors can be classed as "situational" or "overloaded" offenders who will not repeat the offense. Others will do so regardless of the punitive damages. The latter is true of certain publications, for example, which thrive despite libel suits and may cven set aside a contingency fund for this purpose. In the field of newspaper libel, the development of "libel insurance" further reduces the sting of damage assessments. Sec Donnelly, The Right of Reply: An Alternative to an Action for Libel, 34 VA. L. Rev. 867 (1948). And publishing concerns often bind themselves contractually to pay damages imposed on their columnists.

19. "[T] The law makes adequate provision .... in the way of a criminal prosecution, for the protection of the community, [and] there can be no reason why relief should not be sought in each case in the manner thus provided." Vincent v. Morgan's Lotisiana \& T.R. \& S.S. Co., 140 La. 1027, 1041, 74 So. 541, 545 (1917).

"Mais comme l'usage des Peines doit être règlê sur l'utilite publique, et non pas sur la passion ou sur la caprice des particuliers; un juge ne fait pas bien laisser une telle chose en la disposition de la personne lèzèe." ("But as the infliction of punishment should be administered with a view to the public good, and not with a view to the passion or caprice of individuals, the judge ought not to leave such a matter to the determination of the injured person.") Puffendorf, Le Droit de la Nature et des Gens 281 (1706), quoted in Fay v. Parker, 53 N.H. 342, 355 (1872).

It is not suggested, however, that criminal action should be substituted for punitive damages in all fields. See text at notes 34-35 infra.

20. In civil actions there is no requirement of a grand jury indictment, no right to refuse to reply on the grounds of self-incrimination, no possibility of executive pardon, no statutory limit on fines, and the mere preponderance of the evidence test rather than the stricter criminal one, is applied. See Fay v. Parker, 53 N.H. 342, $391-92$ (1872).

21. "If [defendant] is made to pay a fine (denominated exemplary, [or] punitory ...) ... he has been just as much pumished as if he had paid to the state the fine. . . . The punishment is the same to the offender... whether [it] entures to the benefit of an individual or of the public." Id. at 390 . See Aldridge, The Indiana Doctrine of Exculplary Danages and Double Jeopardy, 20 IND. L.J. 123 (1945); 21 NoTre D MME LAw. 206 (1946). However the imposition of punitive damages and a criminal fine for the same offense does not violate the constitutional prohibition against double jeopardy. See Brown v. Swineford, 44 Wis. 282 (1878) (dictum). Cf. Helvering v. Mitchell, 303 U.S. 391 (1938). 
his appropriation of damages imposed on the defendant because of "public policy and not on the ground that the plaintiff has any right to the money." 2

Punitive damages are particularly objectionable in defamation litigation. Although compensation for injury caused by libel or slander is undoubtedly proper, an additional award to punish the tortfeasor is neither necessary nor desirable. Libel and slander actions restrict the free expression of ideas.:3 Concededly some legal curtailment of abusive communication is necessary but every additional restraint lessens the scope of free discussion. ${ }^{24}$ And punitive damages readily lend themselves to an unreasonable restriction of free speech, for where the defendant represents minority views the popularity of those views may be on trial. ${ }^{25}$ The jury can award large punitive damages to cripple further activities, whereas compensatory damages alone would often be too small to accomplish this result. ${ }^{20}$ A punitive damage award that is not so excessive as to shock the judicial conscience may be a sufficient financial burden to silence a voice of dissent. ${ }^{27}$

22. New York Evening Post Co. v. Chaloner, 265 Fed. 204, 220 (2d Cir. 1920).

"[W]e are at a loss to know by what process of reasoning, either legal or ethical, the conclusion is reached that a plaintiff in a civil action, ... . is allowed to appropriate moncy which is supposed to be paid for the benefit of the state" Spokane Truck and Dray Cu. v. Hoefer, 2 Wash. 45, 53 (1891). And see Morris, Punitize Damayes in Torl Casss, 44 HARv. L. REv. 1173, 1178 (1931). But see text at note 10 sttpra.

23. Although some courts have stressed the dichotomy between free speech and defimation, others have recognized their close interrelation. Sec, c.g., Brandreth v. Lance, 8 Paige 24, 34 Am. Dec. 368 (N.Y. 1839); Coeur D'Alene Consolidated \& Alining Co. v. Miners' Union, 51 Fed. 260, 267 (C.C. Idaho 1S92) ; Casey v. Cincinnati Typographical Union, 45 Fed. 135, 141-42 (C.C.S.D. Ohio 1891).

This connection is further illustrated by the extension of privilege for certain libelous communications on the ground that in balance the benefit to the public is greater than the harm to the defamed. Foster v. Scripps, 39 Mrich. 376, 383 (1878) (concurring opinion). See Harper, Torts $\& 247$ (1933); Prosser, Torts $\$ 94$ (1941). Sce also Donnelly, The Law of Defamation: Proposals for Reform, 23 MIm: L. Rx: 609 (1949); Hall, Preserving Liberty of the Press by the Defouse of Privilege in Libel Actions, 26 Calif. L. Rev. 226 (1938); Veeder, Freedom of Public Discussion, 23 HAnt. L. Rev. 413 (1910).

24. "Whatever is added to the field of libel is taken from the field of free debate." Sweeney v. Patterson, 128 F.2d 457, 458 (D.C. Cir. 1942).

25. "[W] here the defendant is a commanding, popular, influential person, and the plaintiff of the opposite character, and the local and temporary excitement or prejudice of the time happens to be in favor of the defendant and against the plaintiff, the jury is apt to be reluctant in giving even pecuniary compensation, without adding anything by way of exemplary or punitive damages; while, in a case in which the character of the parties and the circumstances are reversed, the jury will be liable to push their pusser to unwarranted and unconscionable extent ...." Stewart v. Maddox, 63 Ind. 51, 57 (1878).

26. It is reported that in an award against the periodical "The Churchman," compensatory damages of $\$ 200$ were accompanied by punitive damages set at $\$ 10,000$. See Donnelly, The Right of Reply: An Alternative to an Action for Libel, 34 VA. L. REv. 867, 878 n.29 (1948).

27. "The possibility of libel suits or threats of libel surss being used to put some paper or columnists out of business is not to be dismissed lightly. ... Minority groups, in 
Existing legal rules governing the impostion of punitive damages are insufficient to protect the expression of unpopular views. Punitive damages maly usually be assessed where there is any award of general or special damages ${ }^{28}$ and in some jurisdictions even this may not be necessary. ${ }^{20}$ Thus although the plaintiff has suffered little or no actual damage as a result of defendant's actions the jury can impose a punitive damage award of tens of thousands of dollars. ${ }^{30}$ Many courts state that a reasonable relationship between punitive and compensatory damages should exist, ${ }^{31}$ but an analysis of the cases indicates no fixed proportion prevailing between the two.. ${ }^{22}$ Trial and appellate courts have disallowed or reduced punitive damage awards deemed excessive but such holdings have not been based upon any clearly expressed criteria."

particular, are adversely affected by the libel laws. The smaller journals, struggling. along on subsidies or barely managing on their own, are highly vulnerable to libel suits whereas the large enterprises either have no crusading spirit or else can stand the expense of litigation." Id. at 878 . Punitive damage awards of $\$ 1,000-\$ 5,000$ might easily be considered as within the jury's discretion and yet effectively cripple many small publications.

28. In most jurisdictions an award of only nominal damages suffices to support punitive damages. However, a minority of states prohibit punitive damages where there are no actual damages. If actual damages are found, no matter how small, punitive damages may be imposed in almost all jurisdictions. See 1 Catholic U. L. REv. 10\% (1951) ; Comment, 7 Miami L.Q. 517 (1953); 16 Minn. L. Rev. 438 (1932) ; 7 Rutaens L. Rev. 414 (1953) ; 10 Texas L. Rev. 238 (1932); 18 U. CIN. L. Rev. 545 (1949).

29. Wardman-Justice Motors v. Petrie, 39 F.2d 512 (D.C. Cir. 1930) (proof of actual loss sufficient to uphold punitive damages even though no actual damages werc awarded by jury) ; Clark v. McClurg, 215 Cal. 279, 9 P.2d 505 (1932) (entire jury award labeled punitive but court assumed a portion of this was intended as compensatory); McConathy v. Deck, 34 Colo. 461, 83 Pac. 135 (1905) ( $\$ 500$ exemplary award upheld on theory that actual damages occurred although it was not shown in pecuniary terms or awarded by jury). A recurring rationale in these minority cases is that actual damages did occur even though not specifically assessed. See Comment, 17 Iows L. Rev. 413 (1932) ; Comment, 23 Rocky Mr. L. Rev. 206 (1950).

30. In the Reynolds case the jury awarded plaintiff $\$ 175,000$ punitive damages although its award of only $\$ 1$ as general and special damages indicates that it found that Reynolds had suffered no actual injury as a result of defendant's activities.

31. E.g., Crowell-Collier Pub. Co. v. Caldwell, 170 F.2d 941 (5th Cir. 1948); Thompson v. Mutual Ben. Health \& Acc. Ass'n, 83 F. Supp. 656 (N.D. Iowa 1949); Luke v. Mercantile Acceptance Corp. 111 Cal. App. 2d 431, 244 P.2d 764 (1952).

32. See, e.g., Stevenson v. Hearst Consol. Publications, 214 F.2d 902, 910-12 (2d Cir. 1954), cert. denied, 348 U.S. 874 (1954); Bucher v. Krause, 200 F.2d 576, 587-88 (7th Cir. 1952), cert. denied, 345 U.S. 997 (1953); Scalise v. National Utility Service, 120 F.2d 938, 940-41 (5th Cir. 1941).

33. Different verbal standards have been used by appellate courts in reversing jury awards on the ground of excessiveness. See Aladdin Mfg. Co. v. Mantle Lamp Co., 116 F.2d 708, 717 (7th Cir. 1941) ("an injustice has been done"); Livesy v. Stock, 208 Cal. 315, 322, 281 Pac. 70, 73 (1929) ("jury ... prompted by prejudice or passion") ; Crane v. Bennett, 77 App. Div. 102, 112, 79 N.Y. Supp. 66, 74 (1st Dep't 1902) ("enormous"). Cf. Affolder v. New York C. \& St. L.R. Co., 339 U.S. 96, 101 (1950) ("monstrous"); Southern Pac. Co. v. Guthrie, 186 F.2d 926, 931 (9th Cir. 1951) ("grossly excessive").

See 6 Moore, Federal Practice $\$ 59$, p. 3834 (2d ed. 1953), for a discussion of the variance in attitudes among the circuits. Stevenson v. Hearst Consol. Publications, supra 
Therefore the reduction of particular awards has done little to establish standards for future application and generalizations from such decisions are of doubtful value.

Since appellate courts have no power to abolish punitive damages, ${ }^{\text {st }}$ state legislatures should act to protect freedom of speech by abolishing such awards in libel and slander actions. However, this action should not be coupled with an increase in criminal libel prosecutions. The danger of such prosecutions lies in the constant pressure on government officials to retaliate against critics and in the superior resources which these officials have available to silence their opponents. Therefore criminal libel actions often become tools of political warfare. ${ }^{35}$ Civil actions may duplicate this situation, for there are wellfinanced, highly organized, and resourceful private interest groups which might attempt to enforce their views or force others to withhold opinion by bringing or threatening such suits. In both criminal and civil actions mass antagonism may be critically reflected in jury attitudes. Since both actions inhibit freedom of expression, abolition of punitive damages in civil actions should be accompanied by a continued reluctance on the part of enforcenent officers to undertake criminal libel prosecutions.

The rules governing the imposition of damages in defamation actions should also be amended to insure adequate compensation to injured plaintiffs. Juries may currently be awarding punitive damages to cover the actual outlays involved in defamation litigation, since these expenditures cannot be recovered as costs in most jurisdictions. Therefore legislation eliminating punitive damages should authorize juries to award an amount equal to the actual cxpenses of litigation. ${ }^{36}$ Juries should also be empowered to give the plaintiff a right of reply ${ }^{37}$ and to order a published retraction. ${ }^{38}$ Such action would

note 32, is typical of the reluctance of the Second Circuit to tamper with damage verdiets. Bucher v. Krause, supra note 32, illustrates the position of the more willing Seventh Circuit.

34. "[C]ourts have frankly stated their repugnance to the doctrine, yet considercd themselves bound by former decisions in their respective states to still maintain it, appealing to the legislature to relieve them from what they believe to be a pernicious practice." Spokane Truck and Dray Co. v. Hoefer, 2 Wash. 45, 51 (1891). MForeuver sevural states have statutes which specifically authorize punitive damages.

35. The political nature of criminal libel actions is indicated by an analysis of representative cases. See Note, 52 Colux. L. Rev. 521,530 n.75 (1952).

36. In one jurisdiction, Connecticut, "punitive damages" may be awarded only to the extent of costs and legal expenses. This is true of all torts. Craney v. Donavan, 22 Cinn. 236, 102 Atl. 640 (1917). But of. Cons. Gen. STAT. $\$ \$ 8305-10,8312$ (1949). Such expenses should include reasonable amounts for attorney's fees, pretrial investigation and discovery, travel and subsistence of witnesses, court costs, outlays for transcript and exhibits, and other expenditures incidental to the successful prosecution of the action.

37. See Donnelly, The Right of Reply: An Alternatize to an Actions for Libel, 34 VA. L. REv. 867 (1948).

38. In many jurisdictions retraction of libel prior to litigation mitigates damages. See Id. at 893 nn. 51,52 . 
facilitate vindication of impecunious plaintiffs and thus eliminate situations where even a certain victory is too costly to induce one to clear his name.

State legislatures should adopt statutes which provide substantially as follows:

Section X) Only compensatory damages and the damages provided in Section $\mathrm{Y}$ may be awarded in civil actions alleging libel and/or slander (defamation).

Section Y) The jury may in its discretion direct defendant to:

a) pay plaintiff a sum of money equal to the expenses of bringing the suit ;

b) communicate a retraction of defamatory matter in such length and position, and at such time and frequency, as the jury shall determine; and

c) permit plaintiff to reply to defendant in such length and position, and at such time and frequency as the jury shall determine. ${ }^{30}$

39. Right of reply is usually taken to mean that one deeming himself defamed may answer the defaming publication without bringing suit. One state now has a statute authorizing this limited concept of the right of reply. NEv. Conr. Laws $\$ 10506$ (1920). In the proposed statute the jury would be able to make the right of reply available to the injured party after suit is brought as a means of completely vindicating his rights. 